\title{
ROMAN PERIOD SILVER BRACELET AND BROOCH FROM OTASLAVICE, PROSTĚJOV DISTRICT
}

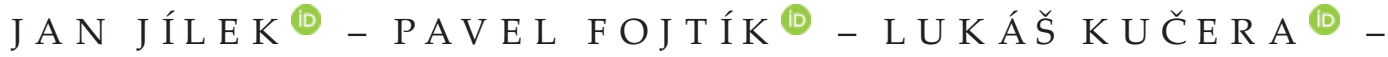 \\ M I R O S L A P O P E L K A
}

\begin{abstract}
A silver shield-head bracelet and a silver eastern-type spring-cover fibula were found in Otaslavice through metal detector survey. Both artefacts are closely related to finds attributed to the Wielbark culture. Their dating conforms to phase B2a or the second third of the $2^{\text {nd }} \mathrm{c}$., respectively.
\end{abstract}

Keywords: Central Moravia, Roman Period, Wielbark culture, silver finds, bracelet, fibula.

\section{INTRODUCTION AND CIRCUMSTANCES OF DISCOVERY}

In October 2020 Radek Környei found two fragments of silver items at the site locally known as 'Kelecká' in the cadastre unit of Otaslavice, Prostějov distr. (Fig. 1). In line with the established cooperation with the Prostějov bureau of the Institute for Archaeological Heritage is handed them over for the purpose of evaluation and safekeeping with the respective museum. The site in question is located to the NW of the present-day village of Otaslavice and it is bisected by a road between the village and the major road connecting Brodek u Prostějova and Prostějov. As for geomorphologic classification, the site is a small hill $(288.9 \mathrm{~m}$ a.s.l.) along a longer ridge which represents the western edge of Drahanská vrchovina, represented here by its part known as Konická vrchovina or, more precisely, its easternmost section known as Myslejovický hřbet (Demek/Mackovčin 2006, 306). The latter protrudes here into the vast SW part of Hornomoravský úval, namely Prostějovská pahorkatina and its section known as Kojetínská pahorkatina (Demek/Mackovčin 2006, 229).

The purpose of this short article is to introduce the new silver finds and to explain them within their relevant Central European contexts. Considering the circumstances of discovery, we cannot offer detailed conclusion regarding chronology. That being said, even these minor finds help paint a decent picture of Central Moravia in second century AD.

\section{Description of items}

1. Fragment of silver shield-head bracelet (ger. Schild-Kopfarminge) deformed by fire, with pseudo-granulation decoration. The head has the following features: fanshaped widened part with small grooves and astragal is attached to a stripe with two rows of pseudo-granulation with wavy line; the conical widening of the head is then attached to a stripe with pseudo-granulation and wavy line. The widened stick-shaped part of the bracelet bears two rows of notches shaped as the letter $\mathrm{V}$ - simplified fishbone motif, and three rows of astragal. The ring of the bracelet itself was represented by a silver stick with the diameter of an irregular circle. Dimensions $26 \times 22 \times$ $11 \mathrm{~mm}$, weight $16.8744 \mathrm{~g}$. Muzeum a galerie v Prostějově, item no. 310916 (Fig. 2: 1).

2. Fragment of eastern-series silver spring-cover fibula (ger. Rollenkappenfibel) damaged by fire, with roof-shaped edge of the bow bearing decoration comprising two vertical lines of astragal. The upper part of the bow is decorated with stamped rings. The knot is one-sided and discshaped and bears fir branch decoration framed by two rows of smaller astragal. The leg is decorated with a pair of stamped rings. Its deformed catch plate is folded; it is assumed that its shape was that of an irregular quadrangle. Dimensions $38 \times 15 \times 12 \mathrm{~mm}$, weight $12.9078 \mathrm{~g}$. Muzeum a galerie v Prostějově, item no. 310917 (Fig. 2: 2).

\section{ARTEFACT ANALYSIS}

Based on its shape, the fragment of the silver bracelet was identified as the Blume I type (Blume 1912, 64, 65, fig. 78; 79). The classification in newer systems is not very straightforward. The fragment in question is partially consistent with the Wójcik I 


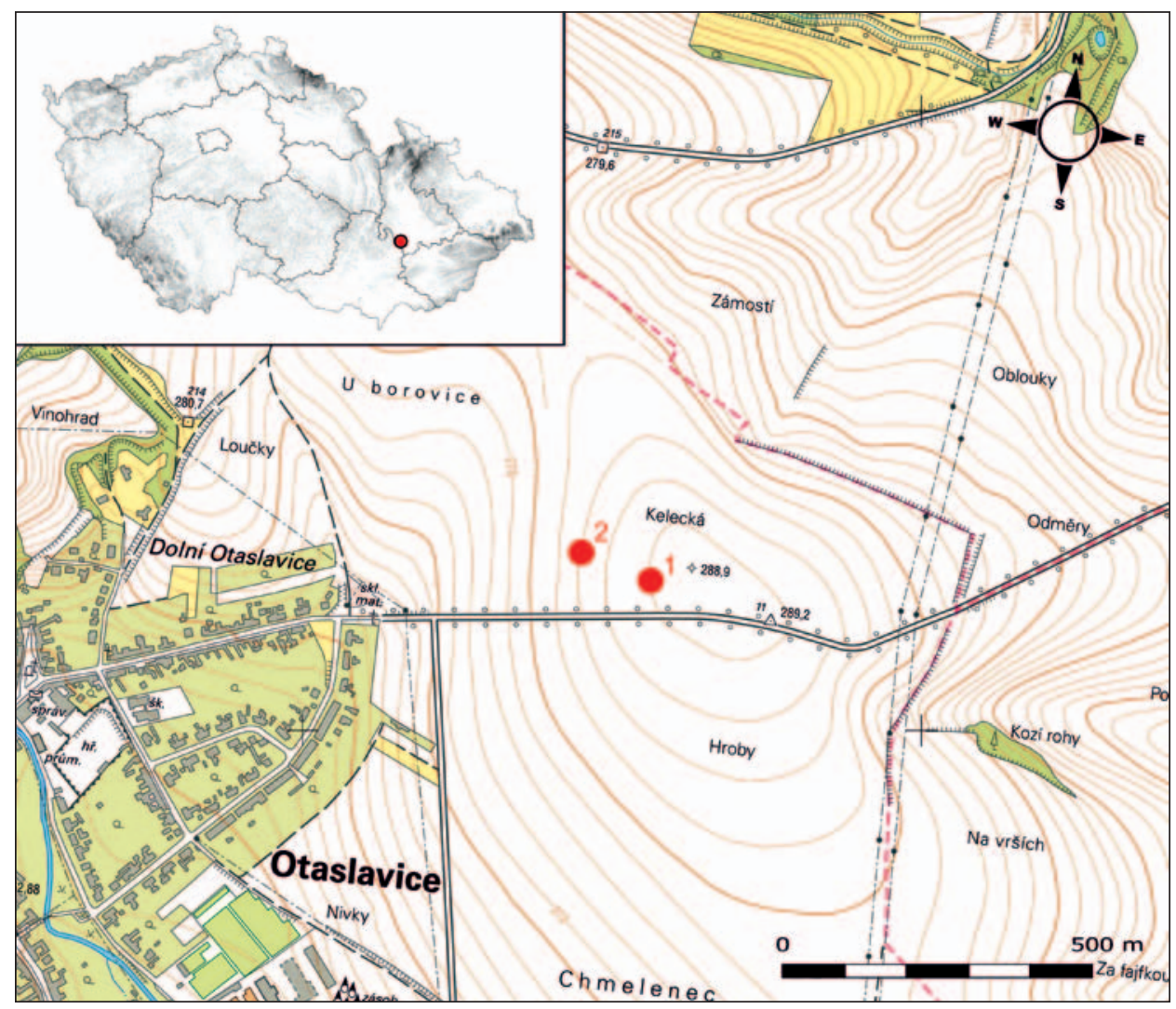

Fig. 1. Otaslavice, Prostějov distr., site of discovery of the silver items in question. 1 - bracelet; 2 - fibula. Map source ČÚZK (created by M. Popelka).

type; that being said, the widening of somewhat off-set edges makes it rather closer to the type Wójcik IIIAb (Wójcik 1978, 45-47, 54, 55, 93, 94, pl. I: 11; IV: 2). Based on more recent classification by J. Strobin (2000, 245, 246, fig. 17) it better corresponds to type I. It is a silver item whose ends were achieved through hammering in a mould, which fact is indicated by two shallow depressions at the rear side of the end of the bracelet (for more details see Natuniewicz-Sekuła 2017, 208, 209; Strobin 2000, 237, fig. 10; 13). Decoration is made via pseudogranulation techniques and depletion - stamping. Both of these processes are documented vis-à-vis the decoration of the aforementioned group of bracelets (cf. Strobin 2000, fig. 22; Ziemlińska-Odojowa 1999, 17, pl. XII: 3).

Only a handful of exact analogies exist, ${ }^{1}$ but we can still identify several very relevant pieces. The shape of shield-head ends of the silver bracelets from grave 336 (Fig. 3: 1) at the Kowalewko burial ground (Skorupka 2001, 89, 149, pl. 100: 7, 8) is the closest item to the Otaslavice piece. Similarities are most prominent with regard to the classification of the decorative ends, with two ribs that separate the conical part. Other similarities include the shaping of the ends of the bracelets - slightly offset and widened. The artefacts from Kowalewko are distinct thanks to decoration. This group can also include bronze artefacts from the burial ground at Babi Dół-Borcz, grave 43 (Fig. 3: 2; Mączyńskal Jakubczyk 2017, 251, fig. 8; Mączyńska/Urbaniak 2007, 26 , 37, fig. 2: 5, 6), as well as yet another bronze item from Chajew (Fig. 3: 3; Kaszewska 1987, 118, 120, fig. 1: $\mathrm{c}-\mathrm{e})$ whose similarities with the find from Otaslavice include the edges of ends and head with two ribs. Less evident examples include finds from the burial ground at Ulkowy, grave 93 (Tuszyńska 2005, 34, 35, pl. XXXVIII: 4, 5) with more complex ends, but with strip-shaped body without set-off, and with different decoration.

As for territory outside of the Wielbark culture, we shall mention the Wójcik IIIAb type golden bracelet from cremation grave in Wulzeshofen (Fig. 3: 4; Beninger 1932, 216, 217, fig. 3; Tejral 2015, 82, 88, fig. 34: 5) where the shape of the band is very similar to that of the find from Otaslavice,

\footnotetext{
1 We would like to thank J. Rajtár (AÚ SAV Nitra), M. Przybyła and E. Rydzewska (IA, Uniwersytet Jagielloński) for the necessary direction.
} 


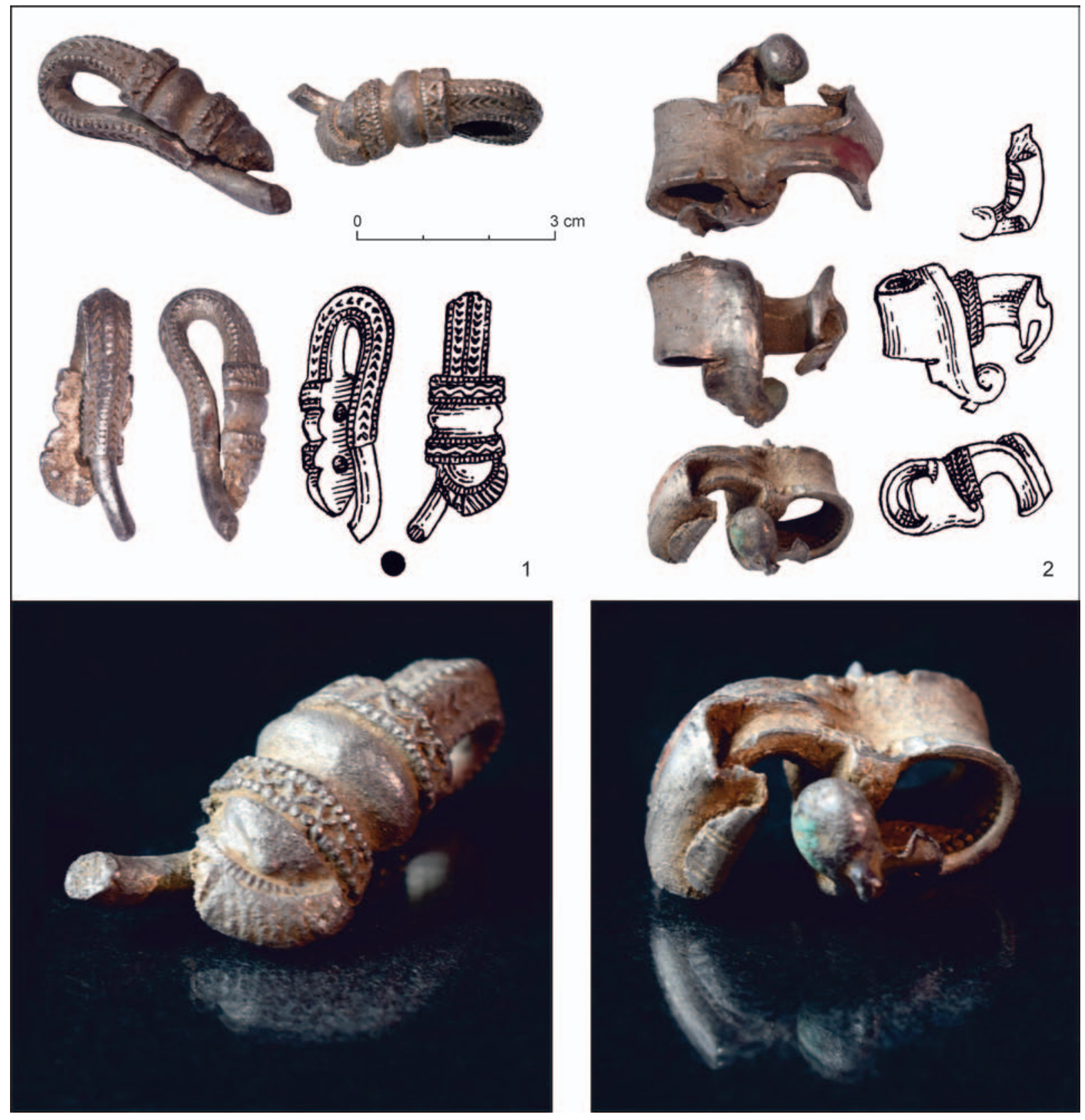

Fig. 2. Otaslavice, Prostějov distr. 1- Blume I type silver bracelet; 2 - A38/39 or 38/41 type fibula (drawing by A. Krechlerová, photo by Z. Golec Mírová).

including the set-off of the widened ends. That being said, the shape of the ends is different, as is decoration. Another similar artefact was found at the cremation burial ground in Sekule (disrupted graves; Fig. 3: 5); this item can be classified as the Wójcik I type (Iván/Kovácsová/Rajtár 2019, 294, fig. 10: 4); this example is also distinctive in terms of decoration. As for Moravian finds, the one closest to the fragment from Otaslavice is a silver fragment from Dobromilice (Čižmár et al. 2013, 299, fig. 2: 5) which is classified as Wójcik IIA or Strobin IB type, respectively (Zeman 2017, 134). It is a silver fragment possibly from settlement context whose end features two ribs.

The dating of the item from Otaslavice can be based, for the most part, on the aforementioned analogies. The burial 336 from Kowalewko is dated as the turn of phase B2b of the Wielbark culture $\left(1^{\text {st }}\right.$ half of the $2^{\text {nd }}$ c.; cf. most recently in Maczyńska $2007,5)$, especially due to the presence of type A 38/41 and type A 120 fibulae (Skorupka 2001, 89, 149). Similar dating may apply to grave 43 at Babi DółBorcz (Maczyńska/Urbaniak 2007, 26, 37), with somewhat later grave 93 from the Ukowy burial ground 


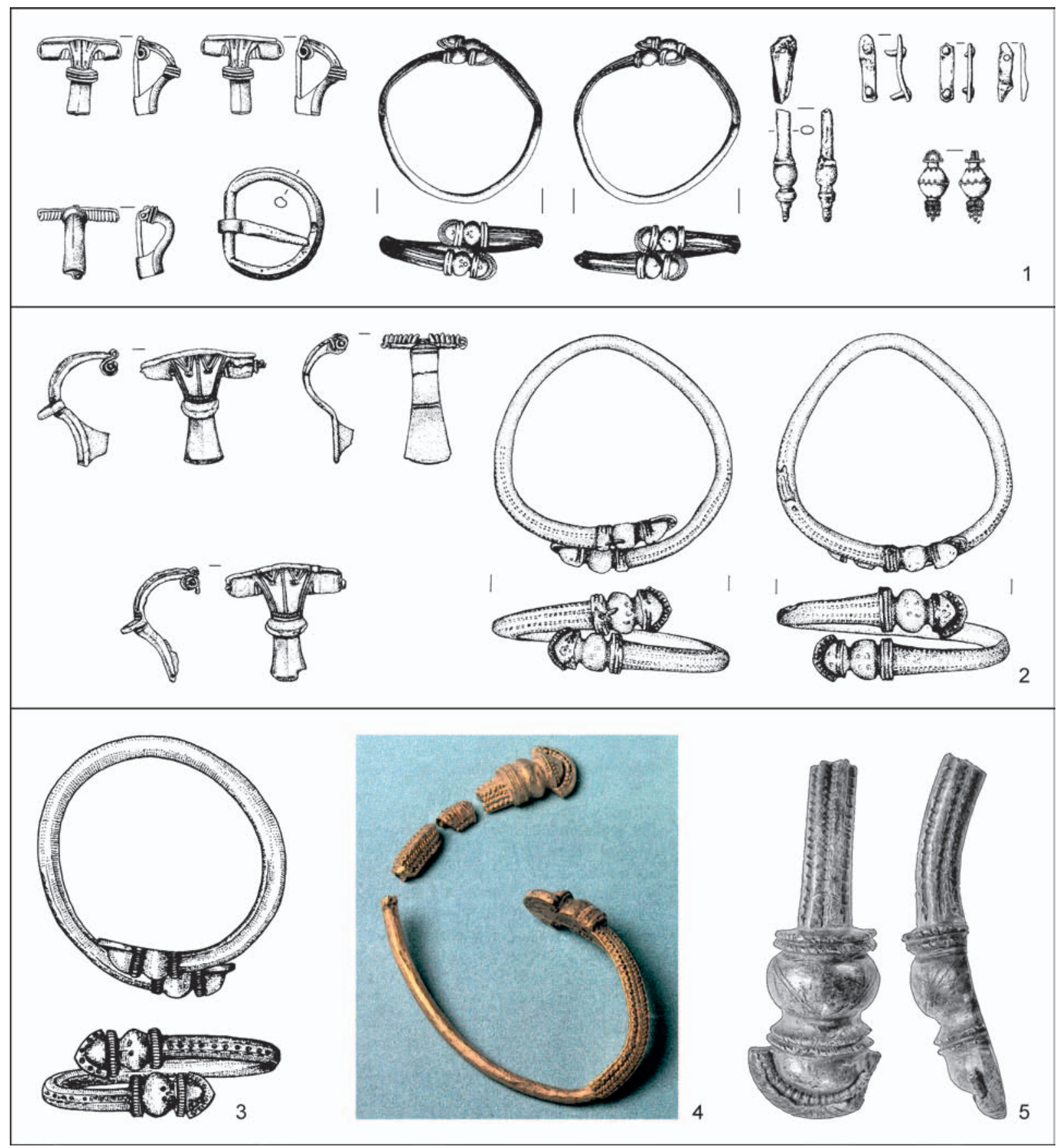

Fig. 3. Selected finds from inhumation graves $(1,2)$ and selected related bracelets (3-5). 1 - Kowalewko, grave 336 (Skorupka 2001); 2 - Babi Dół-Borcz, grave 43 (Mączyńska/Jakubczyk 2017); 3 - Chajew (Kaszewska 1987); 4 - Wulzeshofen (Tejral 2015); 5 - Sekule (Iván/Kovácsová/Rajtár 2019). Various scales.

which is attributed to phases B2b-B2c (Tuszyńska $2005,34,35,46)$, i.e. around mid-2 $2^{\text {nd }} c$. The famous golden find from Wulzeshofen belongs to the period of Marcomannic wars or shortly after them (Tejral 2015, 88, fig. 43). However, the golden jewel is not a typical representative of bracelets of the middle Roman Period. Some experts refer to it as a local imitation or adaptation of Wielbark style (Strobin 2000, 241), or even a prominently stylised late ex- ample (Rajtár 2013, 136, 137) based quite possibly on the Middle Danubian tradition (Iván/Kovácsovál Rajtár 2019, 295).

Within the framework of the chronology of the Roman Period used for the Germanic peoples along the Elbe river on the territory of the former Czechoslovakia, the Otaslavice piece would belong to phase B2a (first half of the $2^{\text {nd }} c .$, cf. Tejral 1986, 106). The golden find from Wulzeshofen suggests that similar 


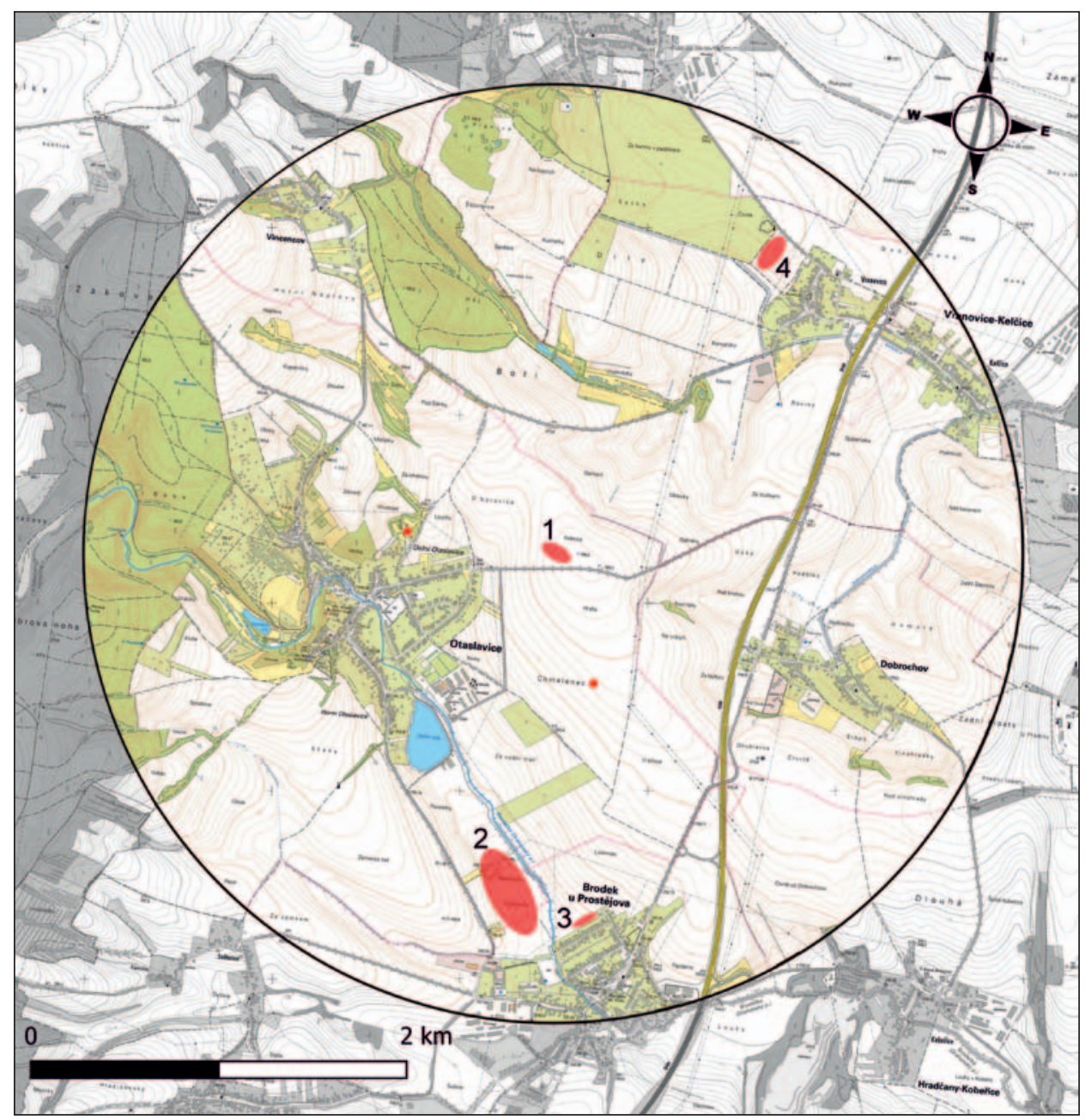

Fig. 4. Topography of selected Roman Period sites in the vicinity of the site of discovery of the silver items in question. 1 - Otaslavice - 'Kelecká'; 2 - Otaslavice/Brodek u Prostějova - 'Bažantnice', larger settlement; 3 - Brodek u Prostějova 'Lískovec', settlement; 4 - Vranovice, below the cemetery, settlement. Red dots without numbers - isolated finds of Roman coins. Map source Č́́ZK (localisation by P. Fojtík).

forms were popular after the mid-2 ${ }^{\text {nd }} \mathrm{c}$. Therefore, second third of the $2^{\text {nd }} \mathrm{c}$. is also a possibility.

For the time being, it is still unknown whether some of these shield-head bracelets from Bohemia and Middle Danubian region constitute Wielbark imports (e.g. Droberjar 2015a, 46-48), local imitations of the Wielbark style (Droberjar 2015a, 46), or evidence of local production traditionally derived from the oldest jewel from an opulent inhumation grave number 5 at Zohor (Iván/Kovácsová/Rajtár 2019, 294, 295; Tejral 1999, 175). At this point, we shall point out that finds attributed to the material culture of the Germanic peoples settled around the Elbe River are often damaged by the heat of the cremation mound, which makes dating more complicated. Debates on local production which, at least in the early stages, could have represented a source of inspiration for Wielbark culture production, are based on individual differences in shapes, early specimens and mapping of sites. This scheme, based essentially on the theory on significant inspiration potential of the Middle Danubian region, which saw progressive development thanks to the proximity of the Roman border, has been analysed several times. However, we must say that, in the case of the bracelets analysed here, we must wait for a complex resolution. A key answer to all main questions could be found in a discovery of workshops or relics thereof, or semi-products, of which there are none so far.

The second find from Otaslavice represents a silver fibula damaged by the heat of fire; its precise dating is therefore based on its condition. Based on the shape of the foot and catch plane, we can identify it as type A38/39 or A38/41, with some degree of discretion. Interestingly, the decoration on the knot on the bow resembles the decoration on the bracelet. The A38/39 type fibulae belong to B2 stage with the 
Tab. 1. Otaslavice, Prostějov distr. XRF data of measurement of silver bracelet and silver brooch (created by L. Kučera).

\begin{tabular}{|c|c|c|c|c|c|c|c|c|c|c|c|c|}
\hline Sample & $\mathrm{Ag}$ & $\mathrm{Cu}$ & $\mathrm{Cr}$ & $\mathrm{Mn}$ & $\mathrm{Fe}$ & $\mathrm{Ni}$ & $\mathrm{Zn}$ & $\mathrm{As}$ & $\mathrm{Sn}$ & $\mathrm{Au}$ & $\mathrm{Pb}$ & $\mathrm{S}$ \\
\hline Bracelet (spot no. 1) & 97.43 & 1.38 & 0.00 & 0.00 & 0.24 & 0.00 & 0.01 & 0.00 & 0.00 & 0.57 & 0.25 & 0.00 \\
Bracelet (spot no. 2) & 95.28 & 1.24 & 0.00 & 0.01 & 2.16 & 0.00 & 0.05 & 0.00 & 0.00 & 0.45 & 0.29 & 0.00 \\
Brooch (spot no. 1) & 95.13 & 2.86 & 0.00 & 0.00 & 0.29 & 0.01 & 0.05 & 0.00 & 0.39 & 0.58 & 0.54 & 0.00 \\
Brooch (spot no. 2) & 93.79 & 1.79 & 1.84 & 0.00 & 1.01 & 0.03 & 0.04 & 0.00 & 0.06 & 0.55 & 0.51 & 0.00 \\
\hline
\end{tabular}

optimal occurrence during the phase B2b of the Wielbark chronology (Mączyńska 2009, 33; Olędzki 1998, 74); and as for absolute chronology, M. Olędzki $(1995,235)$ puts them between 100 and 150, which would correspond to phase B2a by J. Tejral (1986, 106). E. Droberjar (2015a, 38; 2015b, 107, tab. 1) who was the last to summarise the dating of A38/39 type fibulae on our territory did not rule out the possibility of the occurrence of these items over a long period of B2b phase (130/140-150/170). This theory was based on finds in graves in Prague-Vysočany at the site locally known as 'Na Klíčově’ (grave 2/1888; Anonymous 1888, 318-320; Svoboda 1948, fig. 29) and Jevíčko (grave 7; Droberjar/Jarušková 2017, 47) which suggest the second half of the $2^{\text {nd }} c$. (due to the presence of younger artefacts). The aforementioned type of fibulae does not belong to the typical signs of the transitional period of $\mathrm{B} 2 / \mathrm{C} 1$.

\section{ROMAN PERIOD SETTLEMENT IN THE VICINITY OF THE SITE OF DISCOVERY}

Otaslavice, Prostějov distr., being part of the Brodecko micro-region, belongs to the so-called 'old settlement area' with countless archaeological sites and finds, but also increased interest in the study of these sources, which has lasted for more than a century. The strategic location of the village in the proximity of the mouth of Vyškovská brána at the flat Hornomoravský úval is supported by the clearly prominent highest point of the area, the Předina hill, which, at $313 \mathrm{~m}$ a.s.l, constitutes a dominant feature of the area (today it features a transmitter station and an observation tower). It is assumed that in the past it must have been a very important reference point within the geographical centre of Moravia. Regarding spatial and chronological aspects, we shall mention large settlement along the right bank of the Brodečka river which has proved to be rich in finds, specifically at the site locally known as 'Bažantnice', cadastre unit Brodek u Prostějova and Otaslavice (see Fojtík 2019, 60, 61, with a list of available sources and bibliography), which is localised approximately $2 \mathrm{~km}$ to the south of the site of discovery of the two items, thereby allowing for the speculation on the existence of a cremation burial ground (Fig. 4). Traces of a Germanic settlement is also registered at the site locally known as 'Lískovec', cadastre unit of Brodek u Prostějova, where a pit was analysed in 2000 following disruption due to the construction of optical cable network (Šmíd 2001). Next one is located on the slope below the cemetery in the village of Vranovice (random find of a bronze fibula in the collections of the Prostějov Museum and unpublished surface collections of M. Šmíd from 1991). The aforementioned activities during the Roman Period are supported by more frequent isolated finds of Roman coins: as for the area in question, we can mention Hadrian's denarius from the site known as 'Chmelenec' in Otaslavice, or Iulia Maesa's sestertius from the Otaslavice clay pit, as well as an antoninianus of Gordian III from the site locally known as 'Štěpnice' (cf. e.g. Gottwald 1924, 123).

\section{XRF ANALYSIS AND STATISTICAL EVALUATION}

Both silver artefacts (bracelet I Blume type and brooch A38/39 or A38/41 type) were analysed using handle X-ray fluorescence spectrometer Vanta (Olympus, USA). The parameters were as follow excitation energy $0-40 \mathrm{kV}$, acquiring time $60 \mathrm{~s}$ for phase $1(8-40 \mathrm{kV})$ and $10 \mathrm{~s}$ for phase $2(0-8 \mathrm{kV})$, radius of measured area was $9 \mathrm{~mm}$. The surface of both artefacts was polished using corundum polishing adapter. Each spot was measured in three replicates and consequently the data were averaged.

Measured XRF data (Tab. 1) were transferred to statistical software R (R Core team 2020; Wickham 2016) and studied by principal component analysis (PCA) and cluster analysis (CA). Fig. 5 shows the Score Plots (PCA) of XRF data obtained by analysis of silver shield-head bracelet from Otaslavice and from literature, i.e. 13 silver snake-head (Schlangenkopf, Schild-Kopfarmringe) bracelets (4 pcs Wójcik IIIA, 2 pcs Wójcik IVB and 7 pcs Wójcik V type; Natuniewicz-Sekuta 2017, tab. 2; measured in replicates) and 1 silver shield-headed bracelet from Hroznová Lhota I (Zeman 2017, tab. XIV). Note that, 


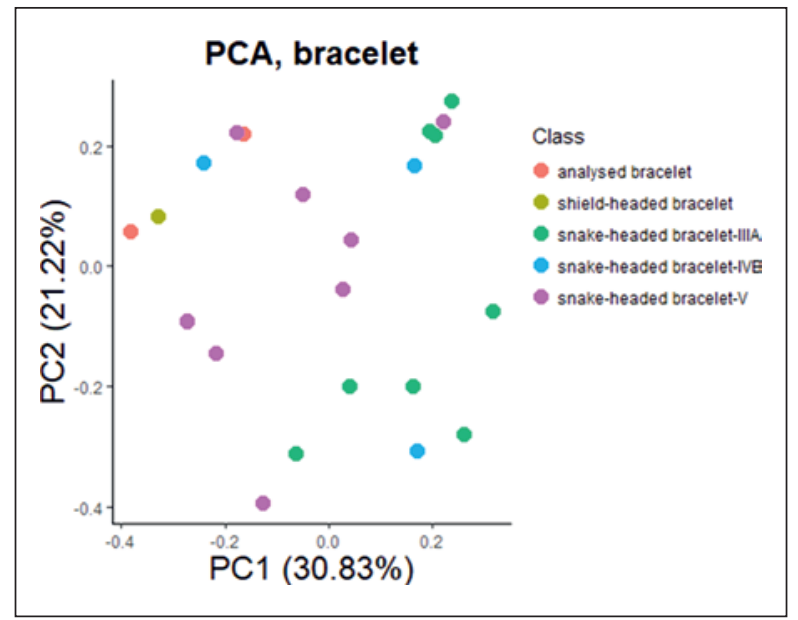

Fig. 5. Otaslavice, Prostějov distr. Principal component analysis of XRF data of silver bracelets (created by L. Kučera).

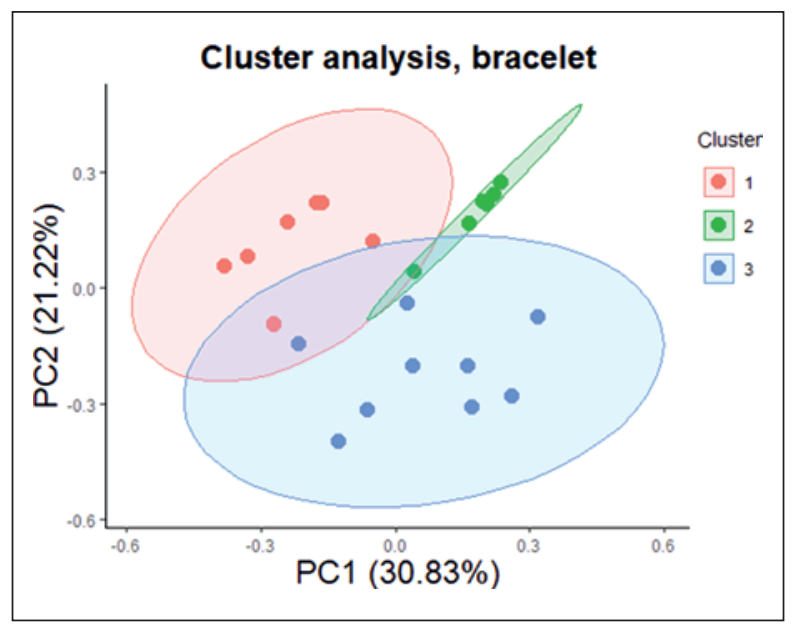

Fig. 6. Otaslavice, Prostějov distr. Cluster analysis of XRF data of silver bracelets (created by L. Kučera).

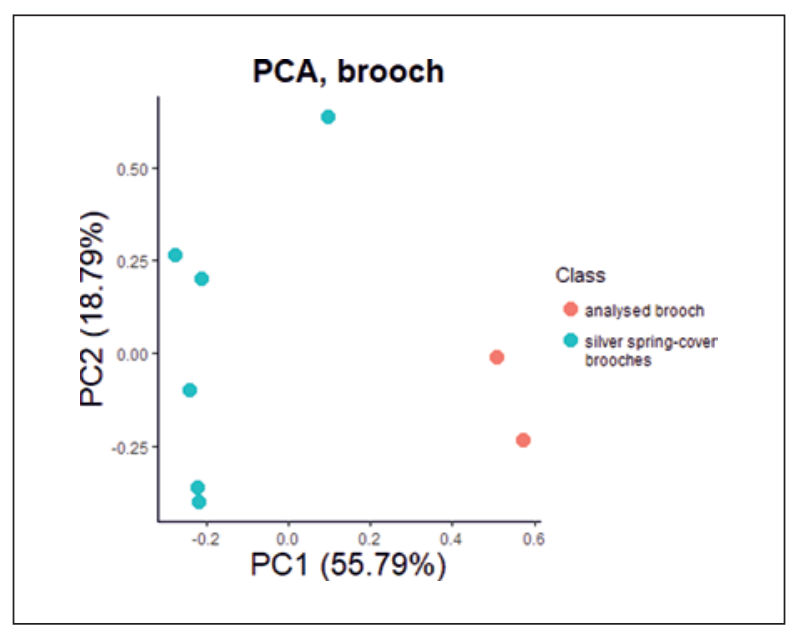

Fig. 7. Otaslavice, Prostějov distr. Principal component analysis of XRF data of silver brooch (created by L. Kučera). both datasets from literature for statistical evaluation were measured by XRF as well. Distinct segregation of analysed bracelet, shield-headed and snake-head bracelets type Wójcik $\mathrm{V}$ from snake-head bracelets type Wójcik IIIA and IVB was observed (except one bracelet Wójcik IVB). The first two components explain $52.05 \%$ of the variability in data. Note, that cumulative proportion of variance with third and fourth component explains $66.55 \%$ and $76.75 \%$ of the variability in data. The cluster analysis proved the presence of three clusters (Fig. 6). The analysed bracelet is located in cluster with silver shieldheaded bracelet from Hroznová Lhota I and four snake-head bracelets (i.e. three Wójcik type $\mathrm{V}$ and one Wójcik type IVB). Based on those results we can conclude that the analysed bracelet has material properties close to the shield-headed bracelet from Hroznová Lhota I and snake-head bracelets belongs to Wójcik type V. The XRF data of silver brooch from Otaslavice was compared with a later silver spring-cover brooches (Natuniewicz-Sekuła 2017, tab. 2). PCA analyses (Fig. 7) shows segregation of studied brooch from the later silver spring-cover brooches. In conclusion, we can say that their material composition is different.

\section{CONCLUSION}

Both silver artefacts represent relatively rare finds on the Moravian and Middle Danubian territory. They are, however, becoming more frequent thanks to increased use of metal detectors (cf. new discoveries of bracelets: Čižmár et al. 2013, 299, 300, fig. 2: 5; 5: 9; Droberjar 2015a, 48; Zeman 2017, 134, map 5). As for workmanship and decorative elements, the finds from Otaslavice reflect the reference to the Wielbark artistic tradition. Considering the 'spatial proximity' of the fibula and the bracelet on the site, similarities in workmanship and condition upon discovery (deformation, evident damage by heat of fire), we can speculate that they come from scattered cremation graves, but this theory cannot be confirmed or ruled out. Making the situation even more complicated, no other finds attributed to the Roman Period were made at the site, which would otherwise help clarify the situation. We have to approach both items solely as finds made through metal detector survey.

From above mentioned results of XRF analysis we can hypothesize that typologically different bracelets Blume I and Wójcik V originating from similar silver alloy. Based on the already published research, a silver processing in barbarian settlements was done by melting of a Roman silver items (including coins) and consequent manufacturing of barbarian jewellery (Droberjar 2014; Voß 2013). 
As for chronological dating, the items belong to the $2^{\text {nd }}$ c. (stage B2). The A38/39 or A38/41 type fibula dates to between B2a and early B2b phases. The bracelet close to the Blume I type dates to between $\mathrm{B} 2 \mathrm{a}$ and B2b phases. Based on Polish analogies the optimal occurrence would fall under the period prior to the half of the $2^{\text {nd }} \mathrm{c}$., but based on the golden bracelet from the cremation grave in Wulzeshofen, we cannot rule out the possibility it dates to after the half of the $2^{\text {nd }} \mathrm{c}$.

The significance of the silver bracelet for the Roman Period community is hard to ascertain with respect to the context of the discoveries. However, if we were to look at the occurrence of silver and gold bracelets on the Wielbark culture territory and outside of this area, we could say that these items were typical in graves of members of elites (Beliavets/Przybyta/Voroniatov 2018, 166, 168, 175, tab. 2). Silver artefacts are more commonly found in graves of women, while they are much rarer in graves of men (Skóra 2015, 176, footnote 44). During the Middle Roman Age in particular they represented typical grave goods in graves of elites. In the case of golden, and quite possibly even silver, items found outside the centre of the Wielbark culture, these jewels are considered as gifts (prestigious goods), and they are perceived as evidence of communication within the Barbaricum, and this phenomenon is in no way contradicting the imitation trends and fascination of the Wielbark aesthetics' (Beliavets/Przybyła/Voroniatov 2018, 174-176, fig. 8).

\section{BIBLIOGRAPHY}

Anonymous 1888 - Anonymous: Z Vysočan. Památky archeologické 14/6, 1888, 318-320.

Beliavets/Przybyła/Voroniatov 2018 - V. Beliavets/M. Przybyła/ S. Voroniatov: Gold rings from Pilipki in Podlasie: some remarks on the connections between the Wielbark culture and Scandinavia at the close of the early and in the beginnings of the late Roman Period. In: B. Niezabitowska-Wiśniewska/P. Łuczkiewicz/S. Sadowski/M. Stasiak-Cyran/M. Erdrich (red.): Studia Barbarica. Profesorowi Andrzejowi Kokowskiemu w 65. rocznice urodzin. Lublin 2018, 158-187.

Beninger 1932 - E. Beninger: Zwei germanische Funde von Wulzeshofen in Niederösterreich. Wiener Prähistorische Zeitschrift 19, 1932, 215-238.

Blume 1912 - E. Blume: Die germanischen Stämme und die Kulturen zwischen Oder und Passarge zur römischen Kaiserzeit. Mannus-Bibliothek 8. Würzburg 1912.

Čižmář etal. 2013-M.Čižmář/J. Čižmářová/M. Kejzlar/E. Kolníková: Detektorová prospekce archeologických lokalit na Moravě v roce 2011. Přehled výzkumů 54/2, 2013, 298-303.

Demek/Mackovčin 2006 -J. Demek/P. Mackovčin (eds.): Hory a níżiny. Zeměpisný lexikon ČR. Brno 2006.

Droberjar 2014 - E. Droberjar: Stříbro na žárovém pohřebišti z doby římské v Jevíčku. In: B. Komoróczy (ed.): Sociální diferenciace barbarských komunit (Archeologie barbaru 2011). Spisy Archeologického ústavu AV ČR Brno 44. Brno 2014, 133-148.

Droberjar 2015a - E. Droberjar: Wielbarské vlivy v Čechách a na Moravě. In: L. Tyszler/E. Droberjar (red.): Barbari superiores et inferiores. Archeologia barbarzyńców 2014. Procesy integracji środkowoeuropejskiego Barbaricum PolskaCzechy-Morawy - Stowacja. Łódź - Wieluń 2015, 35-60.

Droberjar 2015b - E. Droberjar: Markomannen und Superiores Barbari in Třebusice und Jevíčko zur Zeit der Markomannenkriege. Zur Problematik der Übergangsstufe B2/C1 in Böhmen und Mähren. Přehled výzkumu 56/2, 2015, 103-125.

Droberjar/Jarůšková 2017 - E. Droberjar/Z. Jarůšková: Barbaři v pohybu. Jevičko a Malá Haná v době řimské. Boskovice 2017.
Fojtík 2019 - P. Fojtík: Archeologické lokality a nálezy na katastrálním území městyse Brodek u Prostějova (okr. Prostějov). Střední Morava. Vlastivědná revue 48, 2019, 55-96.

Gottwald 1924 - A. Gottwald: Pravěká sídliště a pohřebiště na Prostějovsku. Prostějov 1924.

Iván/Kovácsová/Rajtár 2019 - R. Iván/L. Kovácsová/J. Rajtár: Das germanische Brandgräberfeld in Sekule und seine Bindungen zur Przeworsk-Kultur. In: K. Kot-Legieć/ A. Michałowski/M. Olędzki/M. Piotrowska (eds.): Kultura przeworska, procesy przemian i kontakty zewnętrzne. Łódź 2019, 291-396.

Kaszewska 1987 - E. Kaszewska: Bransolety żmijowate w Polsce środkowej. Prace i Materiały Muzeum Archeologicznego i Etnograficznego w Łodzi. Seria Archeologiczna 34, 1987, 117-124.

Mączyńska 2007 - M. Mączyńska: Wielbark-Kultur. In: Reallexikon der Germanischen Altertumskunde 34. BerlinNew York 2007, 1-20.

Mączyńska 2009 - M. Mączyńska: Der frühvölkerwanderungszeitliche Hortfund aus Łubiana, Kreis Kościerzyna (Pommern). Bericht der Römisch-Germanischen Kommission 90, 2009, 14-416.

Mączyńska/Urbaniak 2007 - M. Mączyńska/A. Urbaniak: Babi Dół-Borcz, pow. Kartuzy, stan. 2. Badania cmentarzyska z okresu rzymskiego w latach 1993-2003. Acta Universitatis Lodziensis. Folia Archaeologica 25, 2007, 25-52.

Mączyńska/Jakubczyk 2017 - M. Mączyńska/I. Jakubczyk: Das Gräberfeld der Wielbark-Kultur von Babi Dół-Borcz, Kr. Kartuzy, FSt. 2. In: B. V. Eriksen/A. Abegg-Wigg/ R. Bleile/U. Ickerodt (Hrsg. - eds.): Interaktion ohne Grenzen. Beispiele archäologischer Forschungen am Beginn des 21. Jahrhunderts. Band I - Interaction without borders. Exemplary archaeological research at the beginning of the $21^{\text {st }}$ century. Volume I. Schleswig 2017, 249-256.

Natuniewicz-Sekuła 2017 - M. Natuniewicz-Sekuła: The Craft of the Goldsmith in Wielbark Culture in the Light of the Finds from the Cemetery at Weklice, Elblacg Commune and Other Necropolis of Roman Period from Elbląg Heights. Technological Studies of Selected Aspects. 
Sprawozdania Archeologiczne 69, 2017, 185-233.

DOI: https://doi.org/10.23858/SA69.2017.008

Olędzki 1995 - M. Olędzki: Typologie, Chronologie und Verbreitung der ostgermanischen Varianten der Rollenkappenfibeln. Praehistorische Zeitschrift 70, 1995, 228-247.

Olędzki 1998 - M. Olędzki: Rollenkappenfibeln der östlichen Hauptserie Almgren 37-41 und die Variante Fig. 42-43. In: J. Kunow (Hrsg.): 100 Jahre Fibelformen nach Oscar Almgren. Internationale Arbeitstagung 25.-28. Mai 1997 in Kleinmachnow, Land Brandenburg. Forschungen zur Archäologie im Land Brandenburg 5. Wünsdorf 1998, 67-84.

R Core Team 2020 - R Core Team: A language and environment for statistical computing. $R$ Foundation for Statistical Computing. Vienna 2020. Online available at: http:// www.R-project.org/

Rajtár 2013-J. Rajtár: Das Gold bei den Quaden. In: M.Hardt/ O. Heinrich-Tamáska (Hrsg.): Macht des Goldes, Gold der Macht. Herrschafts- und Jenseitsrepräsentation zwischen Antike und Frühmittelalter im mittleren Donauraum. Akten des 23. Internationalen Symposiums der Grundprobleme frühgeschichtlichen Entwicklung im mittleren Donauraum. Tengelic, 16.-19. 11. 2011. Forschungen zu Spätantike und Mittelalter Band 2. Weinstadt 2013, $125-150$.

Skóra 2015 - K. Skóra: Struktura społeczna ludności kultury wielbarskiej. Łódź 2015.

Skorupka 2001 - T. Skorupka: Kowalewko 12. Cmentarzysko birytualne ludności kultury wielbarskiej (od połowy I w. n.e. do poczatku III w. n. e.). Archeologiczne badania ratownicze wzdłuż trasy gazociągu tranzytowego. Tom II. Wielkopolska. Cz. 3. Poznań 2001.

Šmíd 2001 - M. Šmíd: Lískovec, "Optické propojení Brno-Ostrava-Český Těšín, úsek Prostějov". Brodek u Prostějova 2001. Nálezová zpráva 16/01. Archiv ÚAPP Brno, v. v. i. Unpublished.

Manuscript accepted 9. 8. 2021

Translated by Lukáš Kučera and Petr Bokůvka

PhDr. Jan Jílek, Ph.D.

Ústav archeologie a muzeologie

odd. klasické archeologie

Filozofická fakulta Masarykovy univerzity

Joštova 220/13

CZ - 66243 Brno

mitridates@post.cz

RNDr. Lukáš Kučera, Ph.D.

Katedra analytické chemie

Přírodovědecká fakulta

Univerzita Palackého v Olomouci

17. listopadu 12

CZ - 77146 Olomouc

lukas.kucera@upol.cz
Strobin 2000 - J. Strobin: Modelowanie w kształtownikach uwagi na temat technik kucia w metaloplastyce kultury wielbarskiej. Światowit 2 (43), fascykul B, 2000, 231-252.

Svoboda 1948 - B. Svoboda: Čechy a římské Imperium. Praha 1948.

Tejral 1986 - J. Tejral: Importe. In: Tabula Imperii Romani. Castra Regina, Vindobona, Carnuntum. Auf der Grundlage der Weltkarte 1:1000 000. M-33 Praha. Praha 1986, 103-109.

Tejral 1999 - J. Tejral: Die Völkerwanderungen des 2. und 3. Jhs. und ihr Niederschlag im archäologischen Befund des Mitteldonauraumes. In: J. Tejral (Hrsg.): Das mitteleuropäische Barbaricum und die Krise des römischen Weltreiches im 3. Jahrhundert. Spisy Archeologického ústavu AV ČR Brno 12. Brno 1999, 137-213.

Tejral 2015 - J. Tejral: Some Remarks on the Transitional Phase between Early Roman and Late Roman Periods in the Region North of the Middle Danube. Přehled výzkumu 56/2, 2015, 43-101.

Tuszyńska 2005 - M. Tuszyńska: Ulkowy. Cmentarzysko kultury wielbarskiej na Pomorzu Gdańskim (badania na trasie autostrady A 1 Gdańsk-Toruń). Gdańsk 2005.

Voß 2013 - H. U. Voß: Chapter 19. Roman silver in 'Free Germany'. Hacksilber in context. In: F. Hunter/K. Painter (eds.): Late Roman Silver. The Traprain Treasure in Context. Edinburgh 2013, 305-319.

Wickham 2016 - H. Wickham: ggplot2. Elegant Graphics for Data Analysis. New York 2016.

Wójcik 1978 - T. Wójcik: Pomorskie formy bransolet wężowatych z okresu rzymskiego. Materiały Zachodniopomorskie 24, 1978, 35-113.

Zeman 2017 - T. Zeman: Střední Pomoraví v době ř́mské. Svědectví povrchové prospekce. Archaeologica Olomucensia 2. Olomouc 2017.

Ziemlińska-Odojowa 1999 - W. Ziemlińska-Odojowa: Niedanowo. Ein Gräberfeld der Przeworsk-und Wielbark-Kultur in Nordmasowien. Monumenta Archaeologica Barbarica 7. Kraków 1999.

PhDr. Pavel Fojtík

Ústav archeologické památkové peče Brno, v. v. i. pobočka Prostějov

Tetín 8

CZ - 79601 Prostějov

pavfojtik@seznam.cz

Mgr. Miroslav Popelka

Ústav archeologické památkové peče Brno, v. v. i. pobočka Hulín

Třebízského 195

CZ - 76824 Hulín

popelka@uapp.cz 
